Received: April, 2011

Accepted: October, 2011

ISSN $2006-6996$

\title{
SUB-ACUTE HEPATOXICITY OF AQUEOUS LEAF EXTRACT OF EUCALYPTUS CAMALDULENSIS IN RATS
}

Imam, A.A. and Wudil, A.M.

Department of Biochemistry, Faculty of Science, Bayero University, Kano - Nigeria.

*Correspondence author: aaimam2000@yahoo.com

\begin{abstract}
Sub - acute toxicity study of the aqueous leaf extract of Eucalyptus camaldulensis was carried out on albino rats. Doses of $250 \mathrm{mg}, 500 \mathrm{mg}, 750 \mathrm{mg}$ and $1000 \mathrm{mg}$ per kilogram body weight of the extract were administered orally for 21 days. The activities of Alanine Aminotransferase (ALT), Aspartate Aminotransferase (AST), Alkaline Phosphatase (ALP) and the concentrations of total protein, and unconjugated bilirubin in the serum of the experimental rats were determined. The results obtained showed no significant difference $(P>0.05)$ when compared to the control rats that were not administered the extract in all the parameters determined. The results indicated that, aqueous leaf extract of Eucalyptus camaldulensis may not have any toxicological effect at the administered doses.
\end{abstract}

Keyword: Eucalyptus camaldulensis, alanine aminotransferase, aspartate aminotransferase, alkaline phosphatase, unconjugated bilirubin.

\section{INTRODUCTION}

Many indigenous plants are used by man in tradomedicinal practices without the actual knowledge of their toxic potentials (Abubakar et al., 2010). Eucalyptus camaldulensis usually called "red river gum" is a tree of the genus Eucalyptus. It is a plantation species in many parts of the world including Nigeria but it is native to Austria where it is widespread especially beside inland water courses. The leaves of Eucalyptus camaldulensis in particular are evergreen. The tree is about $24-40 \mathrm{~m}$ high with stout trunk, the bark is smooth, white grey or buff. The plant has widespread application as a medicinal plant. In Nigeria and some parts of sub - Saharan Africa, its medicinal uses include the use of its oil as a remedy for cough and cold. The gum when boiled with water and sugar, become a liquid drink used to treat pulmonary complaints and as a general anesthetic for tooth ache. An infusion of the bark is used as a wash for some eyes, ophthalmia and is highly effective in treating diarrhea (Boily and Vanpuyvelde, 1986).

The young shoots are chewed for cold, crushed and placed on sore and cuts. Their infusions are used for the relief of aches, pains, severe headaches, and snake bite (Kelly, 1996). The plant is also believed to be efficacious in the management of high blood pressure (Iwu, 1995). It was also reported to have some antibacterial and antifungal properties (Bamaiyi et al., 2004). These medicinal properties of Eucalyptus camaldulensis inspired its widespread usage as a herbal remedy for the ailments mentioned. The growing interest in herbal medicine demands information on the various plant preparations used. The present study was set out to provide information on the safety/toxicity risk potential of sub - acute administration of aqueous leaf extract of Eucalyptus camaldulensis in albino rats.

\section{MATERIAL AND METHODS}

Collection of Plant Material and Preparation of Extract

Fresh leaves of Eucalyptus camaldulensis were collected from the Botanical garden of the Department of Biological Sciences Bayero University, Kano Nigeria. They were air - dried under the shade and pulverized into a coarse powder using pestle and mortar (Onoruvwe and Olurunfemi, 1998). The extract was prepared by weighing fifty grams $(50 \mathrm{~g})$ of the leaves powder into $150 \mathrm{~cm}^{3}$ of distilled water and allowed to stand for 24 hours after which it was filtered. The residue was dried at $50^{\circ} \mathrm{C}$ and weighed. The concentration of the extract was determined from the volume of filterate in $\mathrm{mg} / \mathrm{cm}^{3}$ and administered to the rats according to body weight.

\section{Animals}

Twenty (20) albino rats (Wistar strain) (120 - 200g) purchased from the Physiology Department Animal House Bayero University Kano, Nigeria were used for the experiment. They were kept in clean cages under 12/12 hours under normal light/dark cycle and allowed to acclimatize to the laboratory environment for a period of two (2) weeks before commencement of the experiment. They were fed on standard pellet diet and water ad libitum during experiment period.

\section{Experimental Procedure}

The twenty rats were randomly distributed into five groups of four rats each. Rats in group one served as control and groups 2,3,4 and 5 were administered $250 \mathrm{mg}$, 500mg, 750mg and $1000 \mathrm{mg}$ per kilogram body weight of leaf extract respectively for 21 days. The animals were sacrificed 24 hours after the last dose. Blood samples were collected in clean, dry centrifuge tubes and allowed to clot. They were centrifuged at $3000 \mathrm{rpm}$ for 5 minutes and serum collected for biochemical analysis. 
Activities of alanine amino transferase (ALT) and aspartate amino transferase (AST) were determined by the method of Reitman and Frankel (1957), alkaline phosphatase (ALP) by the method of Rec (1972), total protein (TP) by Biuret method of Henry et al. (1974) while direct and total bilirubin were determined by the method of Zilver and Pannall (1979).

\section{Statistical Analysis}

Data presented were analysed using student $\mathrm{t}$ - test.

\section{RESULTS}

The results presented in table 1 showed no significant differences $(P>0.05)$ in the activities of ALT, AST, ALP, and concentrations of total protein and unconjugated bilirubin in serum of rats administered various doses of Eucalyptus camaldulensis aqueous leaf extract for 21 days when compared with control.

Table 1: Effect of Sub - acute Oral Administration of Aqueous Leaf Extract of Eucalyptus camaldulensis on Rats.

\begin{tabular}{lllllll}
\hline Groups & $\begin{array}{l}\text { Dose } \\
(\mathbf{m g} / \mathbf{k g})\end{array}$ & AST (U/L) & ALT (U/L) & ALP (U/L) & U. Bil. ( $\boldsymbol{\mu m o l / L )}$ & T. Pro. (g/L) \\
\hline 1 & 0.00 & $126.33 \pm 4.73$ & $61.00 \pm 0.56$ & $146.33 \pm 5.13$ & $1.33 \pm 0.58$ & $66.67 \pm 3.51$ \\
Control & & & & & & \\
2 & 250 & $124.67 \pm 4.51$ & $56.67 \pm 6.03$ & $142.34 \pm 3.06$ & $1.67 \pm 0.58$ & $66.67 \pm 3.51$ \\
3 & 500 & $126.00 \pm 6.93$ & $64.33 \pm 4.16$ & $141.65 \pm 3.22$ & $1.33 \pm 0.58$ & $64.00 \pm 1.00$ \\
4 & 750 & $129.00 \pm 5.00$ & $67.33 \pm 6.11$ & $147.33 \pm 2.52$ & $1.50 \pm 0.71$ & $68.66 \pm 1.53$ \\
5 & 1000 & $123.33 \pm 4.93$ & $61.67 \pm 7.64$ & $144.33 \pm 4.93$ & $1.46 \pm 0.35$ & $67.67 \pm 2.52$ \\
\hline
\end{tabular}

Values are mean \pm standard deviation

$\mathrm{N}=$ Number of rats $=4$

\section{DISCUSSION}

The enzymes considered in this study are important and play well - known role in diagnosis of liver cytolysis and damage to the plasma membrane of the liver cells (Schmidt and Schmidt, 1979; Shanhjahan et al., 2004). The ALT and AST play important role in the conversion of amino acids to keotacids and they are major markers of liver damage caused by exposure to toxic substances (Chawla, 1999). The measurement of the concentrations of total protein and unconjugated bilirubin is used to assay for the synthetic and detoxification functions of the liver.

Statistical analysis of the result using student $t$ - test indicated that there is no significant difference $(P>0.05)$ between the values obtained for each parameter in each group when compared with the control after 21 days of extract administration. The result also showed no significant difference among groups with different doses i.e., there is no significant difference between group 5 administered with

\section{REFERENCES}

Abubakar, M.G., Lawal, A. and Usman, M.R. (2010). Hepatotoxicity Studies of Sub-Chronic Administration of Aqueous Stem Bark of Khaya senegalensis in albino rats Bayero Journal of Pure and Applied Sciences 3: (1): $26-28$

Bamayi, H., Kolo, L, Okogun, I.I. and Ijah, U.J.J. (2004). The antimicrobial activities of methanol extracts of Eucalyptus camaldulensis and Terminalia catappa against some pathogenic microorganisms. Journal of Nigerian Society of Experimental Biology 16 (2) 106 - 111.

Boily, Y. and Vapuyvelde, L. (1986). Screening of Medicinal Plants of Rwanda for Antimicrobial
$1000 \mathrm{mg} / \mathrm{kg}$ and group 2 administered with $250 \mathrm{mg} / \mathrm{kg}$ of the extract at $5 \%$ level of significance.

Increase in the level of these parameters in the serum after exposure of experimental animals to xenobiotics (including drugs and medicinal plants extracts) indicate an injury to the liver (Finlayson et al., 1995). The level and type of this injury will depend on the type of xenobiotic and the level of exposure. From the results of this study, no significant changes were observed in the levels of these parameters after 21 days exposure of rats to various doses of the leaf extract. Therefore the results showed no damage to the liver because the levels of the parameters determined (AST, ALT, ALP, U. Bil, and T. Pro) are not significantly different from that of their corresponding controls. From the result of this study, the use of Eucalyptus camaldulensis aqueous leaf extract in traditional medicine could be considered safe at the administered doses.

Activity. Journal of Ethnopharmacology. 6: 1 -13 .

Chawla, . (1999). Practical Clinical Biochemistry (Methods and Interpretations), $2^{\text {nd }}$ edition, Jaypee Brothers Medical Publishers, New Delhi, Pp. $106-118$.

Finlayson, N.D.C., Bouchier, I.A.D., Haslet, C., Edward, C.R.W and Chilvers, E.R. (1995). In: Davidson's Principle and Practice of Medicine $17^{\text {th }}$ edition, Churchill Livingstone Publishers. Pp $484-545$.

Henry, R.J., Cannon, D.C., and Win, J.W. (1974). Method of Protein Determination in Plasma. Clin. Chem. 20: $1362-1363$. 
Iwu, M.M. (1995). Handbook of African Medicinal Plants. CRC Press, Boca Raton, P. 236.

Kelly, S. (1996). Eucalyptus Vol. 11 Thomas Nelson Australia Pp. 22 - 30.

Onoruvwe, O. and Olurunfemi, P.O. (1998). Antibacterial Screening and Pharmacological Evaluation of Dichrostachys cinerea nut. $W$. Afr. J. Bio. Sci. 7: 91 - 99.

Rec. GSC, (1972). Determination of Alkaline Phosphatase. Z. Clin. Chem. Klin. Biochem. 10: $281-291$.

Reitman, S. and Frankel, S. (1957). A Colorimetric Method of Determination of Serum Glutamate Oxaloacetate and Pyruvate Transaminases. Am. J. Clin. Path. 28: 56-61.
Schmidt, E. and Schmidt, F.W. (1979). Enzyme Diagnosis in Disease of the liver and biliary system. Adv. Clin. Enzymol. 1: 239 - 242.

Shahjahan, M., Sabitha, K.E., Jainu, M. and Shymaaladeri, C.S. (2004). Effects of Solanum trilobatum against, carbon tetrachloride - induced hepatic damage in albino rats. Indian J. Med. Res. 120: $194-$ 198.

Zilver, F.J. and Pannall, P.R. (1979). Clinical Chemistry in Diagnosis and Treatment $2^{\text {nd }}$ edition. Lloyd Luke Medical Books Ltd, London Pp. 297 305. 